\title{
Blood lipid metabolites and meat lipid peroxidation responses of broiler chickens to dietary lecithinized palm oil
}

\author{
A. Gheisari ${ }^{1 \#}$, S. S Ale Saheb Fosoul ${ }^{2}$, S. Pourali ${ }^{1}$, E. Nasre Esfahani ${ }^{3}$ \& M. Mohammadrezaei ${ }^{2}$ \\ ${ }^{1}$ Animal Science Research Department, Isfahan Agricultural and Natural Resources Research and Education Center, \\ AREEO, Isfahan, Iran \\ ${ }^{2}$ Young Researchers and Elite Club, Isfahan (Khorasgan) Branch, Islamic Azad University, Isfahan, Iran \\ ${ }^{3}$ Department of Agriculture, Payame Noor University, Tehran, Iran
}

(Received 30 August 2016; Accepted 8 May 2017; First published online 19 June 2017)

\author{
Copyright resides with the authors in terms of the Creative Commons Attribution 4.0 South African Licence. \\ See: http://creativecommons.org/licenses/by/4.0/za \\ Condition of use: The user may copy, distribute, transmit and adapt the work, but must recognise that authors and the \\ South African Journal of Animal Science
}

\begin{abstract}
This trial was conducted to investigate the effects of supplementing saturated and unsaturated fat sources on serum metabolites and meat physiochemical parameters in the diets of broiler chickens. A total of 360 day-old male broiler chicks (Ross 308 ) were used in a completely randomized design with five treatments and six replicates of 14 chicks. The assay diets were developed by applying a basal diet with no supplemented fat and the addition of soybean oil (SO), lecithinized palm oil (LPO), a $50: 50 \mathrm{mix}$ of SO and LPO (ESL), and 75: $25 \mathrm{mix}$ of SO and LPO (HSL) ratios to the basal diet. The inclusion levels of experimental fats were $2 \%$ and $4 \%$ in the starter and growing periods, respectively. Blood samples were collected from broilers to evaluate serum biochemical metabolites on day 41 . Thigh meat samples were provided and analysed after 1,5 and 10 days' storage to evaluate lipid peroxidation at the end of the experiment. Fat and protein contents of thigh muscle and abdominal fat weight were measured and reported. Chickens fed LPO had greater serum triacylglycerol and very low density lipoprotein concentrations compared with those that received other dietary treatments $(P<0.05)$. The fat content of the meat was higher in birds supplemented with SO, LPO and ESL than control $(P<0.05)$. After 5 and 10 days of storage, the values of thiobarbituric acid reactive substance were lower in meat of broilers receiving LPO than SO and HSL $(P<0.05)$. In conclusion, LPO decreased lipid peroxidation during different storage periods compared with SO.
\end{abstract}

Keywords: Blood parameters, broilers, fat type, meat physiochemical parameters

\#Corresponding author: Gheisari.ab@gmail.com

\section{Introduction}

Nowadays, there is an increasing trend to replace animal fat sources with vegetable oils in the diet of broiler chickens. Animal fats (e.g. tallow, poultry fat) are known to have high content of saturated fatty acids (SFA), while vegetable oil sources are rich in unsaturated fat types (Ravindran et al., 2016). Although polyunsaturated fatty acids (PUFA) have greater digestibility than saturated ones, excessive consumption might favour lipid peroxidation, inhibit synthesis of higher homologous of essential fatty acids, alter membrane structures, and impair immune function (Martinez \& Ballabriga, 1987; Kang et al., 2001; Trivedi \& Singh, 2005). The effect of fat type in broiler diets on blood triacylglycerol and lipoprotein concentrations has been demonstrated by researchers (Crespo \& Esteve-Garcia, 2003; Wongsuthavas et al., 2007; Viveros et al., 2009). However, various concentrations of blood metabolites have been observed in response to the consumption of different fat types. For example, fat sources containing SFA increased blood triacylglycerol concentration in broiler chickens (Velasco et al., 2010). The use of several types of palm oil products, such as crude palm oil, refined palm oil, palm olein and palm acid oils in poultry diet, has been reported in the literature (Tancharoenrat et al., 2013). In the current study, lecithinized palm oil (LPO) (Osmosis Nutrition Sdn. Bhd) was assayed. Lecithinized palm oil is a type of processed vegetable fat powder. Lecithin as an emulsifier might contribute to the intestinal fatty acid emulsification and consequently enhance fat digestion. 
To the authors' knowledge, the effect of LPO on blood metabolites of broiler chickens has not been investigated and further research in this field is therefore warranted.

In the poultry industry, maintaining meat quality is a challenge for producers. Safe, effective, and costefficient approaches should be established to increase the stability of broiler meat products during storage (Kang et al., 2001). Dietary administration of synthetic antioxidants and the inclusion of dietary tocopherol are well documented. Nevertheless, certain synthetic antioxidants have been associated with deleterious effects on poultry and consumers (Kang et al., 2001). Accordingly, more research is needed to study other methods for decreasing the peroxidation of lipids in meat products. Lecithinized palm oil has large amounts of SFA, which might be beneficial for meat oxidative stability. Additionally, palm oil contains antioxidants such as oleic and linoleic acids, and vitamin E tocotrienols, which inhibit cholesterol synthesis as well (Chong \& Ng, 1991). Furthermore, the ratio of SFA : monounsaturated fatty acid (MUFA) : PUFA in diets rich in palm oil is close to $1: 1: 1$, which is recommended by the World Health Organization (WHO) (Trivedi \& Singh, 2005). The effective role of palm oil in reducing lipid peroxidation has been shown in the eggs of laying hens (Kang et al., 2001) and meat of broiler chickens (Ura et al., 2008). Jahja et al. (2011) remarked that fat sources consisting of $\mathrm{SO}$, palm oil and linseed oil affect egg production rate, egg weight and yolk proportion. However, research in the field of LPO on the meat oxidative stability of broiler chickens is scarce. The hypothesis of this study was that LPO or its combination with other oils would affect the blood parameters and meat oxidative stability in broiler chickens.

Thus, the objective of the current study was to examine the effects of LPO and SO individually and in combination on serum lipid metabolites and lipid peroxidation in thigh meat of broilers during various storage times.

\section{Material and Methods}

Three hundred and sixty day-old male broiler chicks (Ross 308 ) were purchased from a commercial hatchery and used in this experiment. At arrival, chicks were weighed, wing banded, and assigned to treatment groups so that the initial weight was similar among treatments $(45 \pm 0.5 \mathrm{~g})$. Six replicates comprising 30 cages of 12 chicks each were randomly allotted to five dietary treatments in a completely randomized design across starter (1-21) and growing-finishing (21-42) periods. Diets were in mash form, and the inclusion levels of experimental fats were $2 \%$ and $4 \%$ in the starter and growing periods, respectively. Dietary treatments included a basal diet with no supplemented fat and either soybean oil (SO), lecithinized palm oil (LPO), a $50: 50 \mathrm{mix}$ of SO and LPO (ESL) and a $75: 25 \mathrm{mix}$ of SO and LPO (HSL) ratios added to the basal diet. Experimental diets were formulated to meet or exceed NRC (1994) recommendations (Tables 1 and 2). Chicks were housed in $124 \times 65 \mathrm{~cm}$ battery cages and had free access to feed and water throughout the trial. The ambient temperature was gradually decreased from $33^{\circ} \mathrm{C}$ at first week to $25{ }^{\circ} \mathrm{C}$ on day 21 and was then kept constant. The lighting programme consisted of 23 hours light and 1 hour darkness. All the experimental procedures were evaluated and approved by the Institutional Animal Care and Ethics Committee from the Islamic Azad University, Isfahan (Khorasgan) Branch.

After 12 hours of fasting, blood samples were collected in non-heparinized tubes on day 41 of age from two birds per pen by puncturing the brachial vein. The blood was centrifuged at $2000 \times \mathrm{g}$ for $15 \mathrm{~min}$ to obtain serum (SIGMA 4-15 lab centrifuge, Germany). Individual serum samples were analysed for total cholesterol, triacylglycerol, high-density lipoprotein (HDL), low-density lipoprotein (LDL) and very low density lipoprotein (VLDL) using the kit package (Pars Azmoon Co., Tehran, Iran).

On day 42 of the trial, three birds from each cage were selected according to the average bodyweight in the cage and were slaughtered. Their left thighs were removed, deboned, and ground, then a portion of $100 \mathrm{~g}$ minced thigh muscle was immediately stored in plastic bags at $4{ }^{\circ} \mathrm{C}$ in a refrigerator for 1,5 and 10 days to measure lipid oxidation. The abdominal fat of carcasses was excised, weighed, and reported as live bodyweight basis.

Lipid oxidation was monitored by measuring thiobarbituric acid reactive substances (TBARS), using the method described by Strange et al. (1977). Briefly, $20 \mathrm{~g}$ minced muscle was blended with $50 \mathrm{~mL}$ cold $20 \%$ trichloroacetic acid (TCA) for 2 minutes. The blender contents were rinsed with $50 \mathrm{~mL}$ of water, mixed together, and filtered through a Whatman \#1 filter, and TCA extract was prepared. Then $5 \mathrm{~mL}$ aliquot of the TCA extract was mixed with $5 \mathrm{~mL}$ of $0.01 \mathrm{M}$ 2-thiobabituric acid and heated in a boiling water bath for 45 min. After cooling under running tap water for $10 \mathrm{~min}$, colour development, measured as absorbance at 532 $\mathrm{nm}$ by spectrophotometer (model110 RS; Unico, Dayton, NJ), was identical when a colour development procedure was used with a standard solution of tetraethoxypropane or with TCA extracts of meat. Oxidation products were quantified as malondialdehyde equivalents (mg malondialdehyde $\mathrm{kg}-1$ meat). 


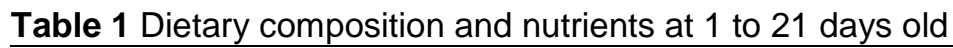

\begin{tabular}{|c|c|c|c|c|c|}
\hline \multirow{2}{*}{ Ingredients } & \multicolumn{5}{|c|}{ Treatments $^{1}$} \\
\hline & Control & so & LPO & ESL & HSL \\
\hline Corn & 583 & 539 & 544 & 542 & 540 \\
\hline Soybean meal & 372 & 396 & 391 & 393 & 395 \\
\hline Soybean oil & 0 & 20 & 0 & 10 & 15 \\
\hline Lecithinized palm oil & 0 & 0 & 20 & 10 & 5 \\
\hline Monocalcium phosphate & 16 & 16 & 16 & 16 & 16 \\
\hline Calcium carbonate & 16 & 16 & 16 & 16 & 16 \\
\hline DL-Methionine & 3 & 3.1 & 3.1 & 3.1 & 3.1 \\
\hline L-Lysine & 1.8 & 1.7 & 1.7 & 1.7 & 1.7 \\
\hline L-Threonine & 0.7 & 0.7 & 0.7 & 0.7 & 0.7 \\
\hline Choline & 1 & 1 & 1 & 1 & 1 \\
\hline Vitamin premix ${ }^{2}$ & 1 & 1 & 1 & 1 & 1 \\
\hline Mineral premix ${ }^{3}$ & 1 & 1 & 1 & 1 & 1 \\
\hline Sodium chloride & 2.7 & 2.7 & 2.7 & 2.7 & 2.7 \\
\hline $\mathrm{NaHCO} 3$ & 1.8 & 1.8 & 1.8 & 1.8 & 1.8 \\
\hline Total & 1000 & 1000 & 1000 & 1000 & 1000 \\
\hline \multicolumn{6}{|l|}{ Calculated nutrient level } \\
\hline ME (Mj/kg) & 12.01 & 12.14 & 12.04 & 12.09 & 12.12 \\
\hline Crude protein (g/kg) & 211.2 & 218.3 & 216.5 & 217.4 & 217.8 \\
\hline Lysine $(\mathrm{g} / \mathrm{kg})$ & 12.6 & 13 & 12.9 & 13 & 13 \\
\hline Methionine + Cysteine $(\mathrm{g} / \mathrm{kg})$ & 6.1 & 6.4 & 6.3 & 6.3 & 6.4 \\
\hline Calcium (g/kg) & 10 & 10 & 10 & 10 & 10 \\
\hline Available phosphorous $(\mathrm{g} / \mathrm{kg})$ & 5 & 5 & 5 & 5 & 5 \\
\hline \multicolumn{6}{|l|}{ Analysed values } \\
\hline Dry matter $(\mathrm{g} / \mathrm{kg})$ & 916.1 & 919.3 & 925.5 & 924.6 & 925.6 \\
\hline Crude protein (g/kg) & 227.8 & 223.7 & 225.6 & 210.7 & 211.9 \\
\hline Ether extract $(\mathrm{g} / \mathrm{kg})$ & 32 & 50.6 & 57.7 & 54.1 & 54.7 \\
\hline Ash (g/kg) & 77.6 & 82.6 & 78.2 & 66.7 & 76.4 \\
\hline
\end{tabular}

'SO: soybean oil, LPO: lecithinized palm oil, ESL: 50:50 mix of SO, LPO: 75:25 mix of SO and LPO

${ }^{2}$ Vitamin premix provided per kg of diet: vitamin A (retinol), 12000 IU; vitamin D3 (Cholecalciferol), 4500 IU; vitamin E (tocopheryl acetate), $70 \mathrm{IU}$; vitamin k3, $3.5 \mathrm{mg}$; thiamine $3 \mathrm{mg}$; riboflavin, $7.5 \mathrm{mg}$; pantothenic acid, $18 \mathrm{mg}$; pyridoxine, $4.3 \mathrm{mg}$; cyanocobalamin, $0.017 \mathrm{mg}$; niacin, $65 \mathrm{mg}$; biotin, $0.3 \mathrm{mg}$; folic acid, $2 \mathrm{mg}$; choline chloride, $600 \mathrm{mg}$; antioxidant $100 \mathrm{mg}$

${ }^{3}$ Mineral premix provided per kg of diet: Fe (FeSO4.7H2O, 20.09\% Fe), $80 \mathrm{mg}$; Mn $\left(\mathrm{MnSO}_{4} \cdot \mathrm{H}_{2} \mathrm{O}, 32.49 \% \mathrm{Mn}\right), 120 \mathrm{mg}$; $\mathrm{Zn}(\mathrm{ZnO}, 80.35 \% \mathrm{Zn}), 110 \mathrm{mg}$; Cu $\left(\mathrm{CuSO}_{4} .5 \mathrm{H}_{2} \mathrm{O}\right), 16 \mathrm{mg}$; I (KI, 58\% I), $1.3 \mathrm{mg}$; Se $\left(\mathrm{NaSeO}_{3}, 45.56 \% \mathrm{Se}\right), 0.3 \mathrm{mg}$

Representative samples of the diets were ground (1-mm) and analysed for chemical composition. The results are summarized in Tables 1 and 2, respectively. Dry matter and crude protein of diet samples were determined using methods 930.15 and 990.03, respectively (AOAC, 2000). Ether extract (EE) of diets was analysed by Soxhlet fat analysis after acid hydrolysis (method 954.02) as described by AOAC (2000). The ash contents were determined based on methods reported by Debon \& Tester (2001). Fatty acid composition of fat sources was determined following the procedure reported by Sukhija \& Palmquist (1988) and results are summarized in Table 3. Meat protein was determined with the standard Kjeldahl copper catalyst method (AOAC, 1990). Intramuscular fat content was determined with the Soxhlet procedure according to the AOAC (1990). 
Table 2 Dietary composition and nutrients at 21 to 42 days old

\begin{tabular}{|c|c|c|c|c|c|}
\hline \multirow{2}{*}{ Ingredients } & \multicolumn{5}{|c|}{ Treatments $^{1}$} \\
\hline & Control & so & LPO & ESL & HSL \\
\hline Corn & 652 & 569 & 578 & 573 & 571 \\
\hline Soybean meal & 306 & 349 & 340 & 345 & 347 \\
\hline Soybean oil & 0 & 40 & 0 & 20 & 30 \\
\hline Lecithinized palm oil & 0 & 0 & 40 & 20 & 10 \\
\hline Monocalcium phosphate & 14.3 & 14.4 & 14.4 & 14.4 & 14.4 \\
\hline Calcium carbonate & 16 & 16 & 16 & 16 & 16 \\
\hline DL-Methionine & 2.5 & 2.9 & 2.9 & 2.9 & 2.9 \\
\hline L-Lysine & 1.2 & 0.9 & 0.9 & 0.9 & 0.9 \\
\hline L-Threonine & 0.6 & 0.6 & 0.6 & 0.6 & 0.6 \\
\hline Choline & 1 & 1 & 1 & 1 & 1 \\
\hline Vitamin premix ${ }^{2}$ & 1 & 1 & 1 & 1 & 1 \\
\hline Mineral premix ${ }^{3}$ & 1 & 1 & 1 & 1 & 1 \\
\hline Sodium chloride & 1.1 & 2 & 2 & 2 & 2 \\
\hline $\mathrm{NaHCO} 3$ & 3.3 & 2.2 & 2.2 & 2.2 & 2.2 \\
\hline Total & 1000 & 1000 & 1000 & 1000 & 1000 \\
\hline \multicolumn{6}{|l|}{ Calculated nutrient level } \\
\hline ME (Mj/kg) & 12.30 & 12.90 & 12.70 & 12.81 & 128.6 \\
\hline Crude protein (\%) & 186.3 & 199.1 & 196 & 197.6 & 198.5 \\
\hline Lysine (\%) & 10.5 & 11.2 & 11 & 11.1 & 11.2 \\
\hline Methionine + Cysteine (\%) & 8.5 & 9.1 & 8.9 & 9 & 9 \\
\hline Calcium (\%) & 9.5 & 9.5 & 9.5 & 9.5 & 9.5 \\
\hline Available phosphorous (\%) & 4.5 & 4.5 & 4.5 & 4.5 & 4.5 \\
\hline \multicolumn{6}{|l|}{ Analysed values } \\
\hline Dry matter & 908.8 & 917.4 & 902 & 916.3 & 915 \\
\hline Crude protein & 196.3 & 209.1 & 201 & 192.2 & 195.8 \\
\hline Ether extract & 30.1 & 73.9 & 71.9 & 63.5 & 72.9 \\
\hline Ash & 90.2 & 70.1 & 71.9 & 63.5 & 72.9 \\
\hline
\end{tabular}

'SO: soybean oil; LPO: lecithinized palm oil; ESL: $50: 50$ mix of SO; LPO: $75: 25$ mix of SO and LPO

${ }^{2}$ Vitamin premix provided per $\mathrm{kg}$ of diet: vitamin A (retinol), $12000 \mathrm{IU}$; vitamin D3 (Cholecalciferol), $4500 \mathrm{IU}$; vitamin E (tocopheryl acetate), $70 \mathrm{IU}$; vitamin k3, $3.5 \mathrm{mg}$; thiamine $3 \mathrm{mg}$; riboflavin, $7.5 \mathrm{mg}$; pantothenic acid, $18 \mathrm{mg}$; pyridoxine, $4.3 \mathrm{mg}$; cyanocobalamin, $0.017 \mathrm{mg}$; niacin, $65 \mathrm{mg}$; biotin, $0.3 \mathrm{mg}$; folic acid, $2 \mathrm{mg}$; choline chloride, $600 \mathrm{mg}$; antioxidant $100 \mathrm{~m}$.

${ }^{3}$ Mineral premix provided per kg of diet: $\mathrm{Fe}(\mathrm{FeSO} 4.7 \mathrm{H} 2 \mathrm{O}, 20.09 \% \mathrm{Fe}), 80 \mathrm{mg} ; \mathrm{Mn}\left(\mathrm{MnSO}_{4} . \mathrm{H} 2 \mathrm{O}, 32.49 \% \mathrm{Mn}\right), 120 \mathrm{mg}$; $\mathrm{Zn}(\mathrm{ZnO}, 80.35 \% \mathrm{Zn}), 110 \mathrm{mg}$; Cu (CuSO4.5H $\left.\mathrm{H}_{2} \mathrm{O}\right), 16 \mathrm{mg}$; I (KI, 58\% I), $1.3 \mathrm{mg}$; Se $\left(\mathrm{NaSeO}_{3}, 45.56 \% \mathrm{Se}\right), 0.3 \mathrm{mg}$

Data were subjected to an analysis of variance appropriate to a completely randomized design using the general linear model (GLM) procedure of SAS 9.2 (SAS Institute Inc., Cary, NC). If a significant effect was detected, differences between treatments were separated with the LSD test. Statements of statistical significance are based on a probability of $P<0.05$, unless otherwise stated. 
Table 3 Fatty acid composition of lecithinized palm oil and soybean oil $(\mathrm{g} / \mathrm{kg})$

\begin{tabular}{|c|c|c|}
\hline & LPO $^{1}$ & $\mathrm{so}^{2}$ \\
\hline \multicolumn{3}{|l|}{ Saturated fatty acids } \\
\hline C12:0 Lauric & 0.8 & - \\
\hline C14:0 Myristic & 12.0 & 0.9 \\
\hline C16:0 Palmitic & 751.6 & 108.9 \\
\hline C17:0 Margaric & 1.5 & 1.0 \\
\hline C18:0 Stearic & 52.9 & 44.6 \\
\hline C20:0 Arachidic & 3.4 & 4.0 \\
\hline C21:0 Heneicosanoic & - & 0.3 \\
\hline C22:0 Behenic & 0.6 & 4.4 \\
\hline C23:0 Tricosanoic & 0.1 & 0.5 \\
\hline C24:0 Lignoceric & 0.6 & 1.5 \\
\hline \multicolumn{3}{|l|}{ Unsaturated fatty acids } \\
\hline C16:1 Palmitoleic & 0.5 & 0.9 \\
\hline C17:1 Heptadecenoic & 0.1 & 0.6 \\
\hline C18:1 Elaidic & 135.3 & 221.2 \\
\hline C18:2 Linoleic & 38.3 & 537.6 \\
\hline C18:3 Linolenic & 2.1 & 70.6 \\
\hline C20:1 Eicosenoic & 0.4 & 2.0 \\
\hline C20:2 Eicosadienoic & - & 0.4 \\
\hline C20:3 Eicosatrienoic & - & 0.2 \\
\hline C20:4 Arachidonic & 0.1 & 0.3 \\
\hline Total fatty acids & 999.2 & 999.9 \\
\hline Saturated & 823.5 & 166.1 \\
\hline Unsaturated & 176.8 & 833.8 \\
\hline Unsaturated to saturated ratio & 0.21 & 5.01 \\
\hline
\end{tabular}

\section{Results}

Results of serum biochemical parameters are summarized in Table 4. Dietary fat sources influenced serum lipids. Accordingly, chickens fed on LPO-added diets had substantially greater triacylglycerol and VLDL concentrations than those birds that received other dietary treatments $(P<0.05)$. Otherwise, serum cholesterol, HDL and LDL concentrations were not affected by dietary treatments.

The least meat fat content was observed in broilers supplemented with control diets (without oil supplementation). This was considerably lower than the other experimental treatments (Table 5) $(P<0.05)$. Otherwise, fat content of the meat in broilers of ESL group was greater than control, LPO, and HSL (Table 5) $(P<0.05)$. Additionally, meat protein content in control birds was significantly higher than SO and ESL (Table 5) $(P<0.05)$. Furthermore, birds fed on control diet had remarkably greater moisture content of the thigh meat than broilers in LPO, ESL and HSL groups (Table 5; $P<0.05$ ). Abdominal fat significantly increased in broilers received LPO compared with the birds in control and SO groups (Table 5) $(P<0.05)$. 
Table 4 Effect of dietary fat types on blood biochemical parameters in broiler chickens

\begin{tabular}{|c|c|c|c|c|c|c|}
\hline \multirow{2}{*}{ Blood Parameters } & \multicolumn{6}{|c|}{ Treatments $^{1}$} \\
\hline & Control & so & LPO & ESL & HSL & SEM \\
\hline Cholesterol (mg/dl) & 121.18 & 113.13 & 121 & 123.83 & 112.08 & 1.906 \\
\hline Triacylglycerols (mg/dl) & $45.64^{c}$ & $50.63^{c}$ & $85.55^{a}$ & $67.79^{b}$ & $60.02^{\mathrm{bc}}$ & 2.924 \\
\hline $\mathrm{HDL}^{2}(\mathrm{mg} / \mathrm{dl})$ & 78.61 & 78.38 & 75.91 & 78.55 & 74.08 & 1.030 \\
\hline $\mathrm{LDL}^{3}(\mathrm{mg} / \mathrm{dl})$ & 35.64 & 25.88 & 33.80 & 34.31 & 30.10 & 0.920 \\
\hline $\operatorname{VLDL}^{4}(\mathrm{mg} / \mathrm{dl})$ & $9.13^{c}$ & $10.13^{c}$ & $17.10^{\mathrm{a}}$ & $13.54^{b}$ & $12.22^{\mathrm{bc}}$ & 0.584 \\
\hline
\end{tabular}

On day 1 of meat storage, TBARS values were greater in birds fed on ESL and HSL than those fed on the control diet (Table 5) $(P<0.05)$, whereas lower values were observed in meat of broilers supplemented with SO than the other groups (Table 5$)(P<0.05)$. As storage time continued until day 5 , TBARS increased in samples related to SO and HSL groups compared with control (Table 5) $(P<0.05)$, while meat samples of LPO and ESL remained somewhat stable with no significant difference in comparison with control. After 10 days of storage, birds fed on SO and HSL-added diets had the greatest meat TBARS values compared with the other dietary treatments (Table 5) $(P<0.05)$.

Table 5 Effect of dietary fat types on meat quality, abdominal fat and thiobarbituric acid reactive substances during different storage times

\begin{tabular}{|c|c|c|c|c|c|c|}
\hline \multirow{2}{*}{ Parameters } & \multicolumn{6}{|c|}{ Treatments $^{1}$} \\
\hline & Control & so & LPO & ESL & HSL & SEM \\
\hline \multicolumn{7}{|l|}{ Meat quality } \\
\hline Protein (\%) & $19.18^{a}$ & $18.37^{\mathrm{bc}}$ & $18.83^{\mathrm{ab}}$ & $18.00^{\mathrm{C}}$ & $18.70^{\mathrm{abc}}$ & 0.125 \\
\hline Fat (\%) & $4.58^{c}$ & $6.03^{a b}$ & $5.98^{b}$ & $7.20^{\mathrm{a}}$ & $5.58^{\mathrm{bc}}$ & 1.267 \\
\hline Moisture (\%) & $73.71^{a}$ & $72.79^{\mathrm{ab}}$ & $72.12^{b}$ & $71.66^{\mathrm{b}}$ & $72.41^{b}$ & 0.211 \\
\hline Abdominal fat (\% BW) & $0.57^{d}$ & $0.79^{\mathrm{cd}}$ & $1.15^{\mathrm{ab}}$ & $1.46^{\mathrm{a}}$ & $0.95^{\mathrm{bc}}$ & 0.230 \\
\hline \multicolumn{7}{|l|}{ TBARS $^{2}$} \\
\hline Day $1(\mathrm{mg} / \mathrm{kg}$ meat $)$ & $0.1096^{c}$ & $0.0825^{d}$ & $0.1181^{b c}$ & $0.1349^{a}$ & $0.1260^{\mathrm{ab}}$ & 0.003 \\
\hline Day 5 (mg/kg meat) & $0.2648^{b}$ & $0.4299^{\mathrm{a}}$ & $0.3155^{\mathrm{b}}$ & $0.2843^{b}$ & $0.4813^{\mathrm{a}}$ & 0.025 \\
\hline Day 10 (mg/kg meat) & $0.9130^{d}$ & $2.4564^{\mathrm{a}}$ & $1.1812^{\mathrm{C}}$ & $1.3645^{\mathrm{c}}$ & $2.7713^{\mathrm{a}}$ & 0.135 \\
\hline
\end{tabular}

\section{Discussion}

In the current study, LPO contained $823.5 \mathrm{~g} / \mathrm{kg}$ SFA versus $176.8 \mathrm{~g} / \mathrm{kg}$ unsaturated fatty acids, while SO contained $833.8 \mathrm{~g} / \mathrm{kg}$ unsaturated fat types (Table 3). The composition of fatty acids is known to have crucial importance in evaluating fat sources of poultry diets (Burlikowska et al., 2010). Greater concentration 
of serum triacylglycerol in broilers supplemented with LPO than SO might be the reason that LPO is rich in saturated versus unsaturated fatty acids, whereas SO is known to be high in unsaturated fat types. The modifying impact of dietary fat types on serum triacylglycerol and lipoproteins has been suggested (Velasco et al., 2010).Generally, fats containing high concentration of SFA increase blood triacylglycerol and reduce the PUFA to SFA ratio of deposited fat in broiler tissues (Velasco et al., 2010). Moreover, lecithin might increase the blood triacylglycerol, as observed in the work of Huang et al. (2008), who demonstrated that $2 \%$ lecithin supplementation increased serum triacylglycerol compared with broilers in control group. Therefore, it seems that dietary supplementation of SO modified the effect of LPO in ESL-fed broilers and resulted in lower concentrations of blood triacylglycerol and VLDL than the LPO group. Mechanisms involving the effect of dietary fat on serum lipid concentrations are not completely understood. However, lack of serum triacylglycerol variations of SO-fed birds compared with chickens in control group might in part be because of the reducing effect of PUFA on hepatic fatty acids and triacylglycerol synthesis. PUFAs have inhibitory effects on $\Delta 9$-desaturase, which might result in impaired secretion of VLDL-cholesterol and triacylglycerol from the liver to the blood (Legrand et al., 1987; Løchsen et al., 1997; Cerqueira et al., 2011). Additionally, consuming diets rich in unsaturated fat types may increase the rate of $\beta$-oxidation and elevate the rate of triacylglycerol uptake from blood to the tissues that decrease the blood triacylglycerol. Noted mechanisms show that there might be a link between VLDL and triacylglycerol concentrations in blood samples of the current trial following LPO consumption. In accordance with the current results, Velasco et al. (2010) reported that broilers received diets containing palm oil had greater serum triacylglycerol than those fed on sunflower oil-supplemented diets. Moreover, Sanz et al. (2000) observed lower blood triacylglycerol concentrations in broilers fed on SO compared with tallow as a saturated fat source. On the contrary, Baldizan et al. (2010) failed to indicate any difference between blood lipid concentrations in broilers receiving peach palm oil compared with crude palm oil, although peach palm oil had $43.5 \%$ less SFA. These discrepancies indicate the need for further research in this field.

Generally, nutrition is a factor that is known to affect the chemical composition of broiler meat. Accordingly, in the current study, birds supplemented with LPO and ESL had higher meat fat content than those in the control group. Nevertheless, the fat content of the meat in broilers receiving LPO and ESL was not different from SO-fed birds. Otherwise, chickens fed on LPO and ESL possessed greater abdominal fat than both control and SO. The concentration of blood VLDL could be an indicator of fat deposition in the abdominal area and meat of broilers (Whitehead \& Griffin, 1984). The current results indicated that serum VLDL in chickens that received LPO and ESL was higher than the other groups. Thereby, lipids that are transferred from the liver via VLDL probably had more pronounced effects on lipid contents in adipose tissue compared with meat fat. This is consistent with the report of Crespo \& Esteve-Garcia (2002). Meat protein content in control birds was the maximum value between groups. In this regard, protein deposition may be increased in response to lower fat content of the meat. It confirms the reduced dietary fat intake of control chickens and consequently lower fat deposition in their meat.

The development of malondialdehyde values in the muscle foods is an indicator of lipid oxidation that can be quantified by spectrophotometry. Malondialdehyde is a group of secondary by-products derived from the degradation of fatty acids. The reaction of aldehydes and ketones with TBA produces TBARS (GuillenSans \& Guzman-Chozas, 1998). The lower TBARS values in the thigh meat of the chickens that received LPO and ESL compared with SO and HSL during storage may be because of greater ratios of SFA accumulation in their meat, since dietary fats influence the lipid composition of chicken muscle (Yau et al., 1991). This shows that palm oil is an appropriate source to use in poultry feeds to protect meat from peroxidation compared with unsaturated fats. Furthermore, the current results suggested that peroxidation of the meat fat during the storage time depends mostly on the fatty acid profile of the consumed fat source, although dietary fat resulted in higher fat deposition in adipose tissue than meat. Reports have indicated that saturated fat sources are more conserved toward lipid peroxidation than unsaturated fatty acids (Lopez-Bote, 2000; Kang et al., 2001). Also, research has demonstrated that lipid peroxidation in the meat could develop during storage time owing to the effect of enzymatic (Asghar et al., 1988) and inorganic iron activity (Kanner et al., 1988). Accordingly, Smink et al. (2008) remarked that randomized palm oil increased saturated fat deposition in the meat of broilers compared with vegetable oils that are rich in unsaturated fatty acids and improved meat firmness. In line with the current results, a diet with high palm oil content reduced TBARS values in eggs of laying hens more than a diet that is low in palm oil (Kang et al., 2001). It has been also reported that graded levels of unsaturated fat sources such as sunflower oil increased lipid peroxidation in thigh and breast muscle in broiler chickens during various storage periods (Gheisari et al., 2004).

\section{Conclusion}

A conclusion that emerged from this study is that LPO and ESL increased serum triacylglycerol and VLDL compared with the other groups, while most of the lipids transferred through VLDL were deposited in 
adipose tissue compared with meat. However, dietary inclusion of LPO as a saturated fat source caused lower lipid peroxidation during long-term storage in comparison with SO or HSL, suggesting that a higher ratio of unsaturated to saturated fat sources might increase lipid peroxidation. It shows the key role of choosing proper fat sources in diet formulation, considering the current production target.

\section{Acknowledgments}

Authors are grateful to Osmosis Nutrition Sdn. Bhd. for providing all the materials and monetary funds that made implementation of this experiment possible.

\section{Authors' Contributions}

AG contributed to the project idea, design and execution of the study. SSASF was in charge of project assistance, executing the study and writing the manuscript. SP and ENE participated in project implementation and MM was involved in statistical analysis of the study.

\section{Conflict of Interest Declaration}

The authors declare that there is no conflict of interests regarding the publication of this manuscript.

\section{References}

AOAC. 1990. Official methods of analysis. 15th ed. Association of Official Analytical Chemists, Washington DC. AOAC. 2000. Official methods of analysis. 17th ed. Association of Official Analytical Chemist, Washington DC.

Asghar, A., Gray, J.I., Buckley, D.J., Pearson, A.M. \& Booren, A.M., 1988. Perspectives on warmed-over flavor. Food. Technol. 42, 102-108.

Baldizan, G., Oviedo, M., Michelangeli, C. \& Vargas, R. E., 2010. Effects of peach palm oil on performance, serum lipoproteins and haemostasis in broilers. Br. Poult. Sci. 51, 784-790.

Burlikowska, K., Piotrowska, A. \& Szymeczko R., 2010. Effect of dietary fat type on performance, biochemical indices and fatty acids profile in the blood serum of broiler chickens. J. Anim. Feed Sci. 19, 440-451.

Cerqueira, F. M., da Cunha, F. M., da Silva, C.C.C., Chausse, B., Romano, R.L., Garcia, C.C.M., Colepicolo, P., Medeiros, M.H.G. \& A.J. Kowaltowski., 2011. Long-term intermittent feeding, but not caloric restriction, leads to redox imbalance, insulin receptor nitration, and glucose intolerance. Free Radic. Biol. Med. 51, 1454-1460.

Chong, Y.H, Ng, T.K. 1991. Effects of palm oil on cardiovascular risk. Med. J. Malaysia, 46, 41-50.

Crespo, N. \& Esteve-Garcia, E., 2002. Dietary polyunsaturated fatty acids decrease fat deposition in separable fat depots but not in the remainder carcass. Poult. Sci. 81, 512-518.

Crespo, N., \& Esteve-Garcia, E., 2003. Polyunsaturated fatty acids reduce insulin and very low density lipoprotein levels in broiler chickens. Poult. Sci. 82, 1134-1139.

Debon, S.J.J., \& Tester, R.F., 2001. In vitro binding of calcium, iron and zinc by non-starch polysaccharides. Food Chem. 73, 401-410.

Gheisari, A., Sarie, A., Pourreza, J., Khoddami, A. \& Gheisari, M., 2004, June. Effects of dietary fat, $\alpha$-Tocopherol and ascorbic acid supplementation on the performance and meat oxidative stability of heat stressed broiler chicks. In Proceedings of the 22nd World's Poultry Congress, (p. 404).

Guillen-Sans, R. \& Guzman-Chozas, M., 1998. The thiobarbituric acid (TBA) reaction in foods: a review. Crit. Rev. Food Sci. Nutr. 38, 315-350.

Hu, F.B., Manson, J.E. \& Willett, W.C., 2001. Types of dietary fat and risk of coronary heart disease: A critical review. J. Am. Coll. Nutr. 20, 5-19.

Huang, J., Yang, D., Gao, S. \& Wang, T., 2008. Effects of soy-lecithin on lipid metabolism and hepatic expression of lipogenic genes in broiler chickens. Livest. Sci. 118, 53-60.

Jahja, A., Grashorn, M.A., Bessei, W., Stuhec, I., 2011. Effect of physical activity of laying hens on egg quality. Arch. Geflügelk. 75, 279-294.

Kang, K.R., Cherian, G. \& Sim, J.S., 2001. Dietary palm oil alters the lipid stability of polyunsaturated fatty acid-modified poultry products. Poult. Sci. 80, 228-234.

Kanner, J., Hazan, B. \& Doll. L., 1988. Catalytic 'free' iron ions in muscle foods. J. Agric. Food. Chem. 36, $412-415$.

Legrand, P., Mallard, J., Bernard-Griffiths, M.A., Douaire, M. \& Lemarchal. P., 1987. Hepatic lipogenesis in genetically lean and fat chickens. In vitro studies. Comp. Biochem. Physiol. Part B Comp. Biochem. 87, 789-792.

Løchsen, T., Ormstad, H., Braud, H., Brodal, B., Christiansen, E.N. \& Osmundsen, H., 1997. Effects of fish oil and n-3 fatty acids on the regulation of $\Delta 9$-fatty acid desaturase mRNA and-activity in rat liver. J. Nutr. Biochem. 8, 408413.

Lopez-Bote, C.J., 2000. Dietary treatment and quality characteristics in Mediterranean meat products. In: Antioxidants in Muscle Foods: Nutritional Strategies to improve Quality. Eds: E. Decker, C. Faustman, CJ Lopez-Bote, Wiley, pp 345-366.

Martinez, M., \& Ballabriga, A., 1987. Effects of parenteral nutrition with high doses of linoleate on the developing human liver and brain. Lipids. 22, 133-138.

Ravindran, V., Tancharoenrat, P., Zaefarian, F., Ravindran, G, 2016. Fats in poultry nutrition: Digestive physiology and factors influencing their utilisation. Anim. Feed. Sci. Technol. 213, 1-21. 
Sanz, M., Lopez-Bote, C.J., Menoyo, D. \& Bautista, J. M., 2000. Abdominal fat deposition and fatty acid synthesis are lower and $\beta$-oxidation is higher in broiler chickens fed diets containing unsaturated rather than saturated fat. J. Nutr. 130, 3034-3037.

Smink, W., Gerrits, W.J.J., Hovenier, R., Geelen, M.J.H., Lobee, H.W.J., Verstegen, M.W.A. \& Beynen, A.C., 2008. Fatty acid digestion and deposition in broiler chickens fed diets containing either native or randomized palm oil. Poult. Sci. 87, 506-513.

Strange, E.D., Benedict, R.C., Smith, J.L. \& Swift, C.E., 1977. Evaluation of rapid tests for monitoring alterations in meat quality during storage: I. Intact. meat. J. Food Prot. 40, 843-847.

Sukhija, P.S. \& Palmquist., D.L., 1988. Rapid method for determination of total fatty acid content and composition of feedstuffs and feces. J. Agric. Food Chem. 36, 1202-1206.

Tancharoenrat, P., Ravindran, V., Zaefarian, F. \& Ravindran, G., 2013. Influence of age on the apparent metabolisable energy and total tract apparent fat digestibility of different fat sources for broiler chickens. Anim. Feed Sci. Technol. 186, 186-192.

Trivedi, R. \& Singh, R.P., 2005. Modification of oils and fats to produce structured lipids. J. Oleo Sci. 54,423-430.

Ura, B., Taharnklaew, R. \& Kijparkorn, S., 2008. Effects of vitamin E in crude palm oil on growth performance, lipid peroxidation and tissue vitamin $\mathrm{E}$ concentration in broilers. Proc. $7^{\text {th }}$ Chulalongkorn Univ. Vet. Ann. Conf., Bangkok, Thailand.

Velasco, S., Ortiz, L.T., Alzueta, C., Rebolé, A., Treviño, J. \& Rodriguez, M. L., 2010. Effect of inulin supplementation and dietary fat source on performance, blood serum metabolites, liver lipids, abdominal fat deposition, and tissue fatty acid composition in broiler chickens. Poult. Sci. 89, 1651-1662.

Viveros, A., Ortiz, L.T., Rodríguez, M.L., Rebolé, A., Alzueta, C., Arija, I., Centeno, C. \& Brenes, A., 2009. Interaction of dietary high-oleic-acid sunflower hulls and different fat sources in broiler chickens. Poult. Sci. 88, 141-151.

Whitehead, C.C., \& Griffin, H.D., 1984. Development of divergent lines of lean and fat broilers using plasma very low density lipoprotein concentration as selection criterion: the first three generations. Br. Poult. Sci. 25, 573-582.

Wongsuthavas, S., Yuangklang, C., Vasupen, K., Mitchaothai, J., Srenanual, P., Wittayakun, S. \& Beynen, A. C., 2007. Assessment of de-novo fatty acid synthesis in broiler chickens fed diets containing different mixtures of beef tallow and soybean oil. Int. J. Poult. Sci. 6, 800-806.

Yau, J.-C., Denton, J. H., Bailey, C.A. \& Sams, A.R., 1991. Customizing the fatty acid content of broiler tissues. Poult. Sci. 70, 167-172. 